International Business Management 13 (9): 423-428, 2019

ISSN: 1993-5250

(C) Medwell Journals, 2019

\title{
Identifying the Causes and Impact of Cost Increase and Schedule Delays in Commercial Construction Projects in Kuwait
}

\author{
Ahmad A. Al-Fadly \\ Department of Business Administration, Gulf University for Science and Technology, \\ Mubarak Al-Abdullah, Kuwait
}

\begin{abstract}
Commercial builders in Kuwait face increased competition as a result of a slowdown in spending and delays to project schedules. In addition, they are challenged by lapses in cash-flow as project owners postpone contract payments. For this reason, many high-rise building contractors have declared job cuts and are attempting to lower costs. The wealth of any country is measured by its performance in construction project delivery within the construction industry which is inherently large, unstable and requires great capital expenditures. For Kuwait economies, the commercial construction business constitutes a major component of the construction industry. The aim of the study reported in this research was to identify the causes and impact of cost increase and schedule delays in commercial construction projects in Kuwait. The study was carried out in Kuwait through a questionnaire that surveyed 300 building owners and developers of commercial projects in Kuwait. The results of the study confirmed the prevalence of cost increase and schedule delays in commercial construction projects in Kuwait. What is more, the study established delay of payments to be the number one cause of schedule delays in the Kuwait commercial construction industry, followed by the financial processes in client organizations and the financial difficulties that accompany the delayed release of funds by client organizations, contract adjustments and economic hardships. The study concludes that all the issues recognized in this study need to be carefully managed, so as to avoid risks that are attributable to them through enhanced risk and project management performed by clients, contractors and consultants.
\end{abstract}

Key words: Kuwait construction, commercial projects, cost, time, competition, risks

\section{INTRODUCTION}

The main goal of any construction development is simple: to construct something. What separates the construction industry from other industries is that its projects are large, constructed on-site and most unique (Ahmed et al. 2003). The state of Kuwait was the only country in the Gulf Corporation Council (GCC) marketplace to record a peak in contract awards last year. In addition, Kuwait offered some of the region's top construction opportunities in 2018 with many of its 95 billion dollars of planned projects seen as important to the country's financial development (Kuwait, 2017). The rising boom in commercial building construction activities has in turn, attracted the attention of a rapidly-growing number of high-rise building contractors. But many of the commercial building projects have not been completed on time and these costly delays draw many complaints from the people benefiting from the projects. Changes are integral to the building construction process and are manipulated to respond to newly developed circumstances. Wide or poorly managed changes may cause significant negative outcomes on project schedules and cost performances. Two main problems facing the construction business are project delays and cost overruns. In today's highly competitive economic setting, the need for finishing construction projects within the specified parameters of cost, time frame and expected performance expectations is becoming increasingly important (Jumana, 2016).

Delays in construction projects are a common phenomenon and commercial building construction projects are no exception. They are usually accompanied by cost overruns. According to, Aibinu and Jagboro (2002) project schedule delays and over-expenditures arise due to a wide range of reasons. If the project timeline or costs exceed their planned targets, customer fulfillment is compromised and the funding profile would no longer align with the budget and further issues in scheduling could occur. These process failures have a debilitating consequence on contractors, clients and consultants in terms of development in organizational conflict, lawsuits, protracted negotiations, cash-flow problems and a general feeling of mistrust or insecurity. This complex issue is not unique to the country's construction industry but is also experienced in economies too (Aibinu and Jagboro, 2002). This study will have outlined major causes and effects of cost escalation and schedule delays on the commercial construction industry in Kuwait. 
Int. Business Manage., 13 (9): 423-428, 2019

\section{Literature review}

Increase of cost: Delays in construction projects are very common at the onset of a project in most parts of the world even with the introduction of modern management techniques (Mezher and Tawil, 1998). Time delays and the associated cost burden usually lead to adverse effects on the development of national economies, contribute to substantial financial losses as well as hold back growth in the construction industry. A long-term study of a number of commercial works projects which was conducted in United States, showed the negative and costly impacts of time delays (Tavakoli and Kakalia, 1993). The study investigated several design-bid-build state construction projects between the years of 2010-2014 and concluded that large-size and long-duration projects had significantly higher costs and schedule overruns than smaller sized or short-duration projects (Shrestha et al. 2013).

Halloum and Bajracharya (2012) argue the reason for time delays and cost overruns are lapses in the following domains: preliminary estimation and contingency planning; scope definition; coordination of roles and tasks between involved parties and the monitoring and control of systems. Most of the construction projects in developing countries are characterized by time delays and projects with significant delays may end up losing their economic justification which in turn may result in the cancellation of the project contract (Sweis, 2013). Mahamid (2011) pointed to the following problems due to schedule delay in commercial projects: disturbance of the budget execution plan; misunderstanding of owner's plans and resulting public inconvenience. The next major causes of construction delivery delays were described as insufficient data gathering and surveying before design, higher than expected increases in costs due to inflation and repair and reconstruction work due to errors during construction.

Additional significant causes of construction interruption were inappropriate planning, poor site management and insufficient or limited team experience. The majority of the cost increase is encountered in lump sum contracts while fewer happen in unit-price contracts and even less in reimbursement contracts (Sambasivan and Soon, 2007). Researchers of this phenomenon have described the following causes of an increase in cost: awarding contracts to the bottom bidder, site circumstances, incompetent subcontractors, poor site supervision, erroneous estimates and client-led change orders (Kasimu, 2012).

Schedule delay: Construction project delays can cause damaging losses to owners who have devised contract supplies and project developments to anticipate, mitigate and compensate for such delays, so that, they could protect their assets (Brennan, 2002). Delays in project schedules reflect a condition where in a construction project is not accomplished within the planned period. Time is an essential part of every plan for construction contract work. There is a connection between the timetable, project conditions and the scope of the work. Changes to any one or more of the aforementioned variables can affect the compensation level and time of completion (Shrestha et al. 2013). Construction projects regularly experience delays in the project schedule. Numerous factors affect completion periods of construction projects and it has been argued that it is essential to create awareness of causes, occurrence and influence of delays in the delivery of a project (Falqi, 2004).

According to, Ahmed et al. (2002), construction project delays can be grouped in four broad groups based on how they operate contractually: compensable excusable delays, non-excusable delays, non-compensable excusable delays and concurrent delays. Mansfield et al. (1994) argue that the most important factors affecting construction schedules were funding and payment for finished works, poor contract management, changes in site conditions, shortage of materials and improper planning. Ahmed et al. (2002) examined the causes of delays in project schedules in the construction industry and concluded that the most prevalent causes of construction project delays included approval of working or shop drawings, settling bills with contractors and the resulting cash-flow difficulties during construction, changes of design, work schedule conflicts among subcontractors, the executive bureaucracy of the clients, slow decision making, design mistakes, lack of labour and poor labourer skills. The problems of the construction industry could be nested in three layers such as shortages or insufficiencies in industry infrastructure (i.e., securing resources) issues caused by clients and consultants and the ineffectiveness of contractors (Promkuntong and Ogunlana, 2006).

According to, Kumaraswamy and Chan (1995), construction schedule delays can be separated into three groups: those over which neither party to the contract has any control those over which the construction owner has control and those over which any sub contractor has control. It is commonly recognized that delays of the first type are part of the contractor's usual and legitimate financial risk and hence should give neither party grounds for financial recompense but that the contract accomplishment date should be extended in order to defend contractors from liquidated compensation claims for late accomplishment. Otherwise, in the extreme, a contract may be rejected due to frustration.

It is also recognized that for delays of type two, the contractor should obtain fair and reasonable payment whereas for type three delays, the contractor must accept full responsibility (Ahmed et al. 2002). 
A construction project may be delayed partly or completely because of a seemingly endless list of variables. These include bad weather, a lack of material estimates an erroneous forecast of production output an inaccurate estimation of equipment production; a lack of materials such as shortages of tools and equipment; inadequate labour skills; project limits; poor planning and design flaws and ad hoc changes. Some of these variables could result in late project completion; however, others may have no effect on the construction schedule. However, all delays, generally, cost money. The main variables of cost increase have been generally identified as unpredictable climate, inflationary material price, inaccurate material estimates, project drawing revisions, contractor's lack of geographical knowledge, contractor's lack of project type experience and unfamiliarity with local regulations (Sambasivan and Soon, 2007).

Resource shortages: Resource management has been widely studied in many developing countries (Tavakoli and Kakalia, 1993) but less, so in developed countries (Abdullah, 1985). Material planning embraces calculating, ordering, collating and scheduling. The output will suffer if the materials planning process is not executed correctly. Another matter is material shortages. For example, yearly steel shortages have long been a topic of debate within the Middle East construction industry because in the majority of the projects, clients demand local brands (Wibisono, 1994). In addition, cement and steel shortages escalate the cost of other materials as those materials are a constituent of many others. As materials account for some $65 \%$ of the overall cost of high-rise construction (Ilyas et al., 2019; Kaming et al., 1997) their impact on cost overruns can be very high. Another major issue is the shortage of a skilled workforce to cope with the boom in construction activities in many GCC countries. In fact, skilled workers are often not actually skillful having only gained their knowledge on the job site and learning construction skills through trial and error. Training institutions that could train construction craftsmen are still limited in the country (Jumana, 2016).

Experience: Kaming et al. (1997) state that a lack of contractor understanding of particular types of projects is characteristic in many countries. The subsequent lack of technological knowledge causes delays and cost increases. How can schedulers plan the length of activities if they are not familiar with the method of construction or the related optimal sequencing of study? How can estimators or quantity surveyors budget equipment or operators if they do not know the outputs of equipment or the wage costs for operators? furthermore, there is often a lack of environmental data for geographical problems. The construction of nearly all civil engineering and building projects will undergo multiple adjustments and adaptations as the project is executed. The magnitude of these changes depends upon a number of variables, not least significant of which are the thoroughness of the pre-design site examination; the wholeness of working drawings accessible at the time of estimate or tender and unpredictable conditions during construction. Design variations inevitably lead to differences in original cost and schedule programmes (Ellis and Thomas, 2002). In addition, labour is part of but separate from, other resources as it possesses specific characteristics. The productivity of labour is a function of skill and motivation. Poor labour output has been examined intensively in many countries and problems have been recognized (Sambasivan and Soon, 2007).

\section{MATERIALS AND METHODS}

The target population for this research was management individuals working on high-rise construction projects and commercial building owners in Kuwait. The questionnaire survey which was designed to determine the major causes and effects of cost increase and schedule delays commercial projects was targeted at 300 participants using the disproportionate stratified sampling technique. To ensure that the findings of the survey included all possible factors that would cause cost increase and schedule delays in commercial building construction projects in Kuwait, only 262 questionnaires were considered in the study. The valid response rate was 87.3\%.

\section{RESULTS AND DISCUSSION}

A survey questionnaire was used to further investigate the findings to which the results could be generalized. Participants of the questionnaire survey were asked to rate the causes of cost increase and delays in schedule with respect to their significance on a Likert scale ranging from 1-4 where $1=$ not significant, 2 = slightly significant, $3=$ significant and 4 = very significant. Results of survey questionnaires showed there were five major causes of cost increase that predominantly affected commercial construction projects in Kuwait. Figure 1 limited experience scored the highest at a weighted average of $73 \%$, followed by poor site management which scored $63 \%$ and the cause of higher than expected increase in costs scored a $61 \%$. Confusion regarding owner's plans scored at $52 \%$ and disturbance of the budget execution plan scored a 54\%.

Results showed that there were 7 major causes of schedule delay increases that predominantly affect commercial construction projects in Kuwait. Schedule delay scored 54\% while approval of working drawings 


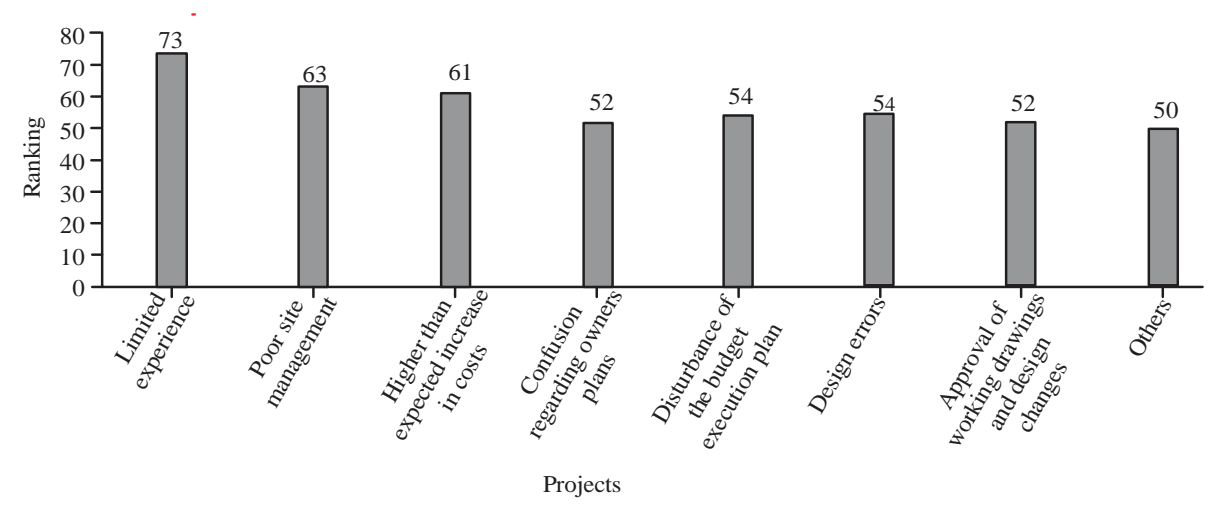

Fig. 1: Major causes of cost increase and schedule delay in commercial projects and their ranking in Kuwait

and design changes came in at $52 \%$. The others were conflicts in work schedules of subcontractors, slow decision making/executive bureaucracy in the client's organizations, design errors, labor shortages and inadequate labour skills all of which scored 50\%. The results found the main factors affecting cost increases and time delays in commercial building construction in Kuwait as follows:

- Limited experience of contractors

- Large and/or long-duration projects resulting in higher cost and schedule overruns

- Misunderstanding of owner's plans

- Repair and reconstruction work due to errors during construction

- Awarding contracts to the bottom bidder

- Site circumstances

- Incompetent subcontractors

- Poor site supervision

- Hasty approval of working or shop drawing drawings

- Delays in settling bills with contractors

- Lack of labour and/or unskilled labour

- Poor contract management

- Contractor's lack of geographical knowledge

From the factors noted above and the analysis of study results and the literature recognized that spending extra monies during scheduling and design will decrease the time and mitigate costs by preventing unexpected conditions such as design errors and oversights and developing arrangements that will support the most efficient approach. In the study, changes in plans and work exceeding the billed amount resulted which directly impacted the project costs and projected deadline which contractors subsequently were forced to address lest they lose the project entirely. The study revealed that the timely accomplishment of construction projects must be made a priority. Critical properties should be applied to construction projects based on the significance of the project, however, the over-ambitious period design was created due to the initial delay. The selected project period for the civil works and procurement of equipment of all the sites were squeezed keeping total project accomplishment deadline intact, whatever the project size in terms of cost and scope. This plan ultimately had resulted in construction delay in every site.

The study also identified that the performance of a project team must be accountable. In a construction project, from a quality management perspective, cooperation among collaborators is necessary as it has profound impact on construction supervision. Consequently, the performance of the team in accomplishing a project in a timely manner should be measured for all contributors who make up the project team i.e., project representatives, consultants, workers, contractors line agencies etc. Individuals and organizations must be held responsible for timely completion at every level. However, project forecasting is one of the keys to tracking the delays. To complete the timely achievement of a project, the owner and the contractor must recognize together how the contractor plans to execute the work and allow for the different components of the work. In the study, a lack of accountability at sites due to neglectful consultants was also one of the causes of construction delay.

Greater knowledge and skills must be available at every stage of the building process. Reduction of mistakes and omissions requires knowledge and skills gained from the practice and the experience of the professionals involved in the project. Project progress and design must have access to construction knowledge and contribution. In the project, the uses of construction management techniques remained nil. The study also found that the majority of the consultants are working in an outdated manner, so, current construction knowledge was not being integrated into the design of the project. The contractors were also working in a traditional way, so, they could not apply any innovative construction techniques. In the case 
of the construction equipment, the contractors used only concrete mixture machine and compressing vibrators and the concrete pouring was done manually. All of these factors had also contributed to the delay in construction work.

Insufficient planning of building activities leads to inaccurate material estimates as well as inexact estimation of labor team production rates. As there is no dependable source for material estimating, nor any standard form of documentation for construction operatives, contractors cannot effortlessly assess the volume of construction craftsmen. Such errors in estimating may cause subsequent delays in production. A labour shortage is another important factor which frequently leads to poor productivity. Untrained workers do not produce good results and scarcity of material might slow down their productivity in expectation of a delivery. The inaccuracy of cost evaluations is primarily due to the absence of standard cost data.

\section{CONCLUSION}

In Kuwait, there are large investments made in commercial construction projects and developments in the performance of the sector are significantly impeded by the increased costs and schedule delays experienced on many projects. The study found delay of payments to be the number one cause of schedule delays in the Kuwait commercial construction industry, followed by inefficient financial procedures in client organizations and financial difficulties that accompany the delayed release of funds, contract adjustments and economic hardships. Material procurement, variations in plans drawings, employee and labor problems, equipment inaccessibility, poor supervision, construction errors, poor on-site direction, changes in specifications and labour disputes were among the major causes of schedule delays.

These reasons combine to impede the rate of delivery of commercial construction. Delays and an increase of cost tend to unbalance the initial cost advantage analyses, considering that much of the money used to construct the building is borrowed and has to be paid back with interest. All the issues recognized in this study need to be carefully managed, so as to avoid risks attributable to them. This calls for enhanced risk and project management performed by clients, contractors and consultants.

\section{REFERENCES}

Abdullah, M.L., 1985. Work study in the construction industry. National Productivity Centre, Kuala Lumpur.
Ahmed,. M., S. Azhar, M. Castillo and P. Kappagantula, 2002. Construction delays in Florida: An empirical study. Department of Community Affairs, Florida, U $\quad S \quad$ A https://www.researchgate.net/profile/Salman_Azha r3/publication/228584635_Construction_Delays_in _Florida_An_Empirical_Study/links/53f3f2830cf2 56ab87b79be6.pdf

Ahmed, S.M., S. Azhar, P. Kappagntula and D. Gollapudil, 2003. Delays in construction: A brief study of the Florida construction industry. Proceedings of the 39th Annual ASC Conference, April 10-12, 2003, Clemson University, Clemson, SC., pp: 257-266.

Aibinu, A.A. and G.O. Jagboro, 2002. The effects of construction delays on project delivery in Nigerian construction industry. Intl. J. Project Manage., 20: 593-599.

Brennan, D.S., 2002. Tools to manage the risks of construction delays. Shopping Center Legal Update, USA.

Ellis, R.D. and H.R. Thomas, 2002. The root causes of delays in highway construction. Proceedings of the 82nd Annual Meeting of the Transportation Research Board, July 25, 2002, Washington, DC., USA., pp: 1-16.

Falqi, I., 2004. Delays in project completion: A comparative study of construction delay factors in Saudi Arabia and the United Kingdom. M.Sc. Thesis, School of the Built Environment, Heriot-Watt University, Edinburgh Campus, Edinburgh, Scotland.

Halloum, M.A. and A. Bajracharya, 2012. Cost and time overrun revisited: A study on the infrastructure construction projects in Abu Dhabi, UAE. Proceedings of the 3rd International Conference on Construction in Developing Countries, July 4-6, 2012, Bangkok, Thailand, pp: 4-6.

Ilyas, M., J. Li and I. Ullah, 2019. Study of factors causing time and cost overrun in pre-construction project (a case study of Malaysia). World J. Eng. Technol., 8: 1-12.

Jumana, A., 2016. Kuwait construction sector continues to grow. The Big Lead, New York, USA.

Kaming, P.F., P.O. Olomolaiye, G.D. Holt and F.C. Harris, 1997. Factors influencing construction time and cost overruns on high-rise projects in Indonesia. Constr. Manage. Econ., 15: 83-94.

Kasimu, M.A., 2012. Significant factors that causes cost overruns in building construction project in Nigeria. Interdiscip. J. Contemp. Res. Bus., 3: 775-780.

Kumaraswamy, M.M. and D.W. Chan, 1995. Determinants of construction duration. Constr. Manage. Econ., 13: 209-217.

Kuwait, 2017. The report. Oxford Business Group, London, England, UK. 
Mahamid, I., 2011. Risk matrix for factors affecting time delay in road construction projects: Owners perspective. Eng. Constr. Archit. Manage., 18: 609-617.

Mansfield, N.R., O.O. Ugwu and T. Doran, 1994. Causes of delay and cost overruns in Nigerian construction projects. Int. J. Project Manage., 12: 254-260.

Mezher, T.M. and W. Tawil, 1998. Causes of delays in the construction industry in Lebanon. Eng. Constr. Arch. Manage. J., 5: 252-260.

Promkuntong, K. and S.T. Ogunlana, 2006. Construction delays in fast-growing economy: Comparing Thailand with other economies. Int. Project Manage., 14: 37-45.
Sambasivan, M. and Y.W. Soon, 2007. Causes and effects of delays in Malaysian construction industry. Int. J. Project Manage., 25: 517-526.

Shrestha, P.P., L.A. Burns and D.R. Shields, 2013. Magnitude of construction cost and schedule overruns in public work projects. J. Constr. Eng., Vol. 2013, 10.1155/2013/935978

Sweis, G.J., 2013. Factors affecting time overruns in public construction projects: The case of Jordan. Int. J. Bus. Manage., 8: 120-129.

Tavakoli, A. and A. Kakalia, 1993. MMS: A materials management system. Constr. Manage. Econ., 11: 143-148.

Wibisono, C., 1994. [Mystery of cement (in Indonesia)]. News Lett. Informasi Indonesian Bus. Data Centre, 14: 4-11. 